\title{
References:
}

1. Привезенцев Ю.А. Рыбоводство / Ю.А. Привезенцев, В.А. Власов. -М.: Мир, 2004. 456 с.

2. Шекк П.В. Індустріальне рибництво: підручник /Одеса: 2017. $227 \mathrm{c}$.

3. Електронний

pecypc.

Режим

доступу:

http://www.rybovod.com/ochistka-vody.php

DOI https://doi.org/10.30525/978-9934-26-047-6-14

\section{КЛІМАТИЧНИЙ СТАН ТА ЕКОЛОГІЧНІ ЗМІНИ ГРУНТОВОГО ПОКРИВУ ЗОНИ ЗАХІДНОГО ПОЛІССЯ УКРАЇНИ}

\author{
Гаврилюк В. А. \\ кандидат сільськогосподарських наук, \\ старший науковий співробітник, \\ директор \\ Поліська дослідна станція \\ Наџіонального наукового иентру «Інститут трунтознавства \\ та агрохімії імені О. Н. Соколовського» \\ м. Луиььк, Украӥна \\ Бортнік А. М. \\ кандидат сільськогосподарських наук, \\ стариий науковий співробітник \\ Поліська дослідна станиія \\ Національного наукового иентру «Інститут трунтознавства \\ та агрохімії імені О. Н. Соколовського» \\ м. Луцьк, Украӥна

\section{Мелимука Р. Я.} \\ аспірант \\ Національний науковий центр «Інститут трунтознавства та агрохімії \\ імені О. Н. Соколовського» \\ м. Харків, Україна \\ Родючість - це якісна властивість, яка притаманна лише грунто- \\ вому покриву, та характеризується здатністю безперервно та дос- \\ татньо забезпечувати рослинність одночасно вологою та пожив-
} 54 
ними речовинами [3]. Досягнення цього можливе за сприятливих кліматичних умов та максимально наближених до оптимальних показників якісних характеристик параметрів родючого шару, що свідчить насамперед про екологічний стан грунту.

Станом на сьогоднішній день кліматичні зміни відбуваються не лише на території України, а й у всьому світі, проте саме на теренах Західного Полісся ці зміни є найбільш помітними та непередбачуваними. Окрім істотного підвищення температури повітря, регіональні кліматичні зміни даної зони характеризуються помітними посушливими періодами, що найбільше проявляється під час вегетації рослин. Варто зазначити, що процес аридизації, тобто недостатнього зволоження грунтового покриву, ніколи не був притаманний добре зволоженим землям Полісся.

Полісся - це унікальна природна зона, де переважають грунти легкого гранулометричного складу. Характерною кліматичною особливістю даної зони є тотожність співвідношення тепла та вологи протягом першого та другого теплових періодів. Зокрема для зони Західного Полісся характерним $є$ достатній рівень зволоження із ГДК у теплий період (травень-вересень) 1,30-1,50 [1]

Середньорічні температурні показники у Волинській області в період 1998-2014 років становив 8,5 оС [4]. В 2015 та 2016 році цей показник становив 9,8 оС та 9,13 оС відповідно [5].

Зважаючи на сучасні зміни кліматичних умов суттєво змінюється і умови ведення сільськогосподарських робіт. Одним із головних факторів сьогоденної зміни клімату $є$ підвищення середньорічної температури, відтак за одним із сценаріїв глобального потепління та зміни кліматичних умов (RCP 8.5) за найближчі десятиліття температура повітря на території Полісся підвищиться на $2,68{ }^{\circ} \mathrm{C}$, за умови збереження сучасних тенденцій зміни кліматичних умов. [2, с. 14]

Тож зважаючи на сучасні тенденції зміни кліматичних умов в структурі сільськогосподарського виробництва певні зміни неминучі. Дані зміни внесуть свої корективи як позитивного, так і негативного характеру. Серед передбачуваних позитивних змін очікується: збільшення вегетаційного періоду; можливість ефективного вирощування пізньостиглих сільськогосподарських культур (гібридів), для яких необхідно більше теплових ресурсів; покращення умов та скорочення термінів збирання врожаю; покращення умов перезимівлі багаторічних трав та інші. Із негативного варто відмітити: почастішання та посилення посушливих періодів під час вегетації; прискорення розкладання гумусу в грунтовому покриві; за рахунок сприятливих умов перезимівлі 
збільшиться кількість шкідників та бур'янів; збільшення ризику вимерзання озимих культур через відсутність стабільного снігового покриву в зимові періоди [2].

На високу продуктивність грунтового покриву також неабиякий вплив має екологічний показник, де важливим є рівень забруднення грунту радіонуклідами, які не лише знижують родючість та вносять свої корективи в властивості і функції грунту, але й $є$ небезпечними для життя та здоров'я людини [6].

Найбільшим джерелом забруднення грунтового покриву радіонуклідами $є$ аварія на ЧАЕС, в наслідок якої чи не найбільше постраждали саме сільськогосподарські угіддя зони Полісся. Цезій-137 - найбільший радіаційний забруднювач родючого шару грунту. Площа забруднених земель України Цезієм-137 становить 8327,2 тис. га із 8788,9 тис. га загальної площі України, яка є забрудненою радіонуклідами [1].

Поліською дослідною станцією ННЦ ІГА 3 метою уточнення сучасних темпів розвитку грунтів, які зазнали техногенного забруднення, проводились моніторингові дослідження, в основу яких лягли попередні визначення радіоактивного стану територій зони Західного Полісся, а саме - визначення рівня забруднення Цезієм-137.

В рамках адаптації показників радіоактивного забруднення до особливостей місцевості, науковцями станції, була запропонована наступна градація: 1) показник менший ніж 7,5 кБк/м2, що дозволяє повноцінно та без істотних обмежень займатись веденням сільськогосподарських робіт; 2) 7,5-18,5 кБк/м2 - вирощування сільськогосподарських культур можливе без істотних обмежень; 3) 18,5-37 кБк/м2 - ведення сільськогосподарських робіт $є$ сильно пригніченим на обмеженим; 4) більше 37 кБк/м2 - критична екологічна зона, яка не дозволяє вирощувати сільськогосподарські культури.

Проведені дослідження показали певну закономірність та тенденцію зменшення вмісту радіонуклідного забруднення в грунтовому покриві. Так у 2007-2006 роках результати аналізів були виявлені землі, що перебувають у критичному стані та непридатні до ведення на них сільськогосподарського виробництва із показником забруднення 57,5 кБк/м2, проте вже через 5 років на даній ділянці цей показник був рівні 30,2 кБк/м2, а у 2017-2018 роках - 18,8 кБк/м2, що свідчить про позитивну тенденцію.

Середній показник вмісту Цезій-137 згідно досліджень 2006-2007 років становив 28,9 кБк/м2, тобто дані землі хоч і не перебували у критичному стані, проте ведення сільського господарства було можливе із великими обмеженнями. У 2011-2012 роках даний показник 
знизився до 17,7 кБк/м2, а у 2017-2018 роках - 5,4 кБк/м2, що дозволяє вирощувати сільськогосподарські культури на даних землях без суттєвих обмежень спричинених радіонуклідним забрудненням.

Процеси міграції радіонуклідів вниз по грунтовому профілю протягом усіх років досліджень був мало вираженим. Виявлено, що вміст Цезію-137 у підорному шарі не перевищує 4,1 кБк/м2, а подекуди в шарі грунту нижче 30 см його вмісту взагалі не спостерігається.

Наведені результати досліджень свідчать, що у зоні Західного Полісся покращується екологічний стан, відбувається процес зниження вмісту радіонуклідів в грунті.

\section{Література:}

1. Національна доповідь про стан родючості грунтів України. Від Міністерства аграрної політики України: Присяжнюк М.В., Мельник С.І., Жилкін В.А. та ін. Київ. 2010. 113 с.

2. Іванюта С.П., Коломієць О.О., Малиновська О.А., Якушенко Л.М. / за ред. С.П. Іванюти. // Зміна клімату: наслідки та заходи адаптації: аналітична доповідь. Київ. 2020.110 с.

3. Тихоненко Д.Г., Горін М.О., Балюк С.А., Трускавецький Р.С. та ін. Грунтознавство: Підручник. Київ: Вища освіта, 2005. 703 с.

4. Агрокліматичний довідник по Волинській області / за ред. P. I. Бондарчука, Т. І. Адаменко. Кам'янець-Подільський : [б. в.], 2012. $182 \mathrm{c}$.

5. Тарасюк Н., Федас Т. Агрокліматичні ресурси Волинської області в умовах сучасного клімату. Режим доступу: https://evnuir.vnu.edu.ua/bitstream/ 123456789/15290/1/5.pdf

6. Рекомендації населенню 3 ведення сільськогосподарського виробництва на радіоактивно забруднених територіях Волинської області / М.П. Комар, Р.А. Кухтей, С.В. Щербак, М.Й. Шевчук, М.I. Зінчук та ін. Луцьк: 2003. 57 с. 